九州大学学術情報リポジトリ

Kyushu University Institutional Repository

\title{
Variation of Korean Soybean [Glycine max (L.) Merrill] Varieties based on Leaf-Related Characters
}

HWANG, Tae-Young

International Technology Cooperation Center

GWAK, Sang-Cheol

Department of Crop Science, College of Agriculture, Life Science and Environmental Chemistry, Chungbuk National University

SUNG, Jwakyung

Department of Crop Science, College of Agriculture, Life Science and Environmental Chemistry, Chungbuk National University

CHUNG, Jong-Wook

Department of Industrial Plant Science \& Technology, Crop Science, College of Agriculture, Life Science and Environmental Chemistry, Chungbuk National University

他

https://doi.org/10.5109/2558885

出版情報: 九州大学大学院農学研究院紀要. 65 (1)，pp.15-23，2020-02. Faculty of Agriculture， Kyushu University

バージョン :

権利関係 : 


\title{
Variation of Korean Soybean [Glycine max (L.) Merrill] Varieties based on Leaf-Related Characters
}

\author{
Tae-Young HWANG ${ }^{1}$, Sang-Cheol GWAK ${ }^{2}$, Jwakyung SUNG ${ }^{2}$, Jong-Wook CHUNG ${ }^{3}$, \\ Yoshiyuki SHINOGI ${ }^{4}$, TaeK-Keun $\mathrm{OH}^{5, * *}$, and Hong-Sig $\mathrm{KIM}^{2, *}$
}

\author{
Science for Bioproduction Environment, Faculty of Agriculture, Kyushu University, \\ 744, Motooka, Nishi-ku, Fukuoka city 813-0395, Japan \\ (Received October 24, 2019 and accepted November 14, 2019)
}

\begin{abstract}
This study was carried out to investigate the variation of leaf-related characters and classify varieties of 172 Korean soybean [Glycine $\max$ (L.) Merrill] released from 1913 to 2013 using cluster analysis. The leafrelated characters evaluations were also compared according to released year and utilization types. The results obtained from the present study are summarized as follows: variation coefficient of leaf characteristics of Korean soybean varieties was $15.27 \%$ in leaf length, $23.59 \%$ in leaf width, $24.01 \%$ in leaf width ratio, $16.67 \%$ in leaf thickness, $32.65 \%$ in leaf area, $20.35 \%$ in leaf dry weight, $37.02 \%$ in leaf area ratio, $21.9 \%$ in petiole length, and $47.18 \%$ in petiole weight. Principal component analysis (PCA) of nine leaf characters revealed that the cumulative contribution from the first to the third main component was $84.9 \%$, and it was possible to classify Korean soybean varieties only with the third main component. A total of 6 clusters were formed with an average distance of 1.5. The total number of varieties were classified as follows: 66 (38.4\%) in cluster I, 8 (4.7\%) in cluster II, 8 (4.7\%) in cluster III, 25 (14.53\%) in cluster IV, 2 (1.2\%) in cluster V, and $63(36.62 \%)$ in cluster VI. About $75.1 \%$ of the total number of varieties belong to cluster I and VI. No cultivars produced before 1980 were found in cluster III and V and no cultivars in 1980s were included in III, IV and V, and none of the cultivars of 1990 belong to cluster V. Varieties released after the 2000s were well represented in each cluster. Comparison of leaf characters based on utilization types showed that sauce \& paste belong both in clusters I and VI, bean sprout in I and VI, cooking with rice in I, and vegetable \& earlymaturing in VI. Growth and leaf-related characteristics traits are poor in cluster V and good in cluster VI.
\end{abstract}

Key words: leaf-related characters, Glycine $\max$ (L.) Merrill, cluster analysis, soybean varieties

\section{INTRODUCTION}

In Korea, the first soybean [Glycine $\max$ (L.) Merrill] variety was 'Jangdanbaekmok' produced by separating domestic soybean variety by pure line isolation in 1913, and the first hybrid variety was developed in 1969 characterized with high yield and resistant to mosaic virus. Until the 1970 s, soybean varieties were developed in order to increase yield, and in the 1980s, mechanization-adaptive varieties were developed in response to the declining labor force in rural areas. In the 1990s, the WTO (World Trade Organization) was launched, for this reason the goal of developing new varieties were diversi-

International Technology Cooperation Center, RDA, Jeonju, Jeollabuk-do, 54875, Korea

${ }^{2}$ Department of Crop Science, College of Agriculture, Life Science and Environmental Chemistry, Chungbuk National University, Cheongju, 28644, Korea

${ }^{3}$ Department of Industrial Plant Science \& Technology, Crop Science, College of Agriculture, Life Science and Environmental Chemistry, Chungbuk National University, Cheongju, 28644, Korea

${ }^{4}$ Science for Bioproduction Environment, Faculty of Agriculture, Kyushu University, 744, Motooka, Nishi-ku, Fukuoka city 813-0395, Japan

Depart of Bio-Environmental Chemistry, College of Agriculture and Life Science, Chungnam National University, Daejeon, 34134, Korea

* Corresponding author (E-mail: hongsigk@chungbuk.ac.kr) (H. S. KIM)

** Corresponding author (E-mail: ok5382@cnu.ac.kr) (T.K. OH)

** The authors equally contributed to the present study as co-correspondence. fication of uses and enhancement of quality. Since the 2000s, the goal of breeding has been diversified into high quality, functional food with variety of uses according to demand or user preference, resistance to insect damage and high-value added product, leading to the 178 varieties developed until 2014 (Lee et al., 2015).

The plant type of soybean is affected by the cultivation conditions, but it is also very important to know the characteristic of the variety. The variation in plant type of soybean shows a significant difference in the photosynthetic rate and also has a great influence on the yield (Haile et al., 1998; Wells et al., 1982). Soybean is genetically very diverse and has been classified in many different forms, mainly by the characteristics of the main stem and branches (Nakamura et al. 1981; Watanabe et al. 1975; Nagata 1950; Ariga 1943). In addition, the characteristics of leaf-related features in relation to plant type differ by variety, and classifications of these characters have been reported (Kim et al. 2008).

Sawada $(1988,1992)$ proposed a leaflet shape index (LSI) to distinguish the shape of the leaflet. LSI is the ratio of the length and width of the leaflet. He classified the Japanese soybean varieties as broad leaf type with LSI of less than 2.6 and narrow-long leaf type with more than 2.6. Zheng \& Chen (1980) investigated 478 wild type soybeans (G. soja) collected from Jilin Province of China, and classified them into four categories for leaflet shape (ovate, long ovate, lanceolate and linear), and three types for leaflet (small, intermediate and large) according to the area of the leaflet.

Leaf type of soybean was reported to have a signifi- 
Table 1. Number of soybean varieties classified by released year and breeding organization used for this experiment

\begin{tabular}{|c|c|c|c|c|c|c|}
\hline \multirow{2}{*}{$\begin{array}{c}\text { Released } \\
\text { year }\end{array}$} & \multicolumn{5}{|c|}{ Breeding organization } & \multirow{2}{*}{ Total } \\
\hline & $\mathrm{RDA}^{*}$ & ARES & University & Institute & Company & \\
\hline Before 1980 & 18 & - & - & - & - & 18 \\
\hline $1980 \mathrm{~s}$ & 17 & - & - & - & - & 17 \\
\hline $1990 \mathrm{~s}$ & 40 & 3 & - & - & - & 43 \\
\hline From 2000 to 2013 & 64 & 9 & 13 & 3 & 5 & 94 \\
\hline Total & 139 & 12 & 13 & 3 & 5 & 172 \\
\hline
\end{tabular}

*RDA: Rural Development Administration, ARES: Agricultural Research \& Extension Services, Institute: Korea Atomic Energy Research Institute

cant relationship with the seed number per pod and seed size. Jeong et al. (2012) reported that narrow leaflet soybean varieties tend to have more seeds per pod than broad leaflet varieties because thus the leaves are thick and the leaf area ratio is high, and more substances related to photosynthesis will be made per unit leaf area (Dornoff \& Shibles, 1970; Lugg \& Sinclair, 1981). The leaf area ratio means the leaf area to the dry weight of the plant which can be used to show the relative growth rate as a result of the net assimilation rate per unit area of the leaf surface. The relative growth rate helps us to understand the relationship between photosynthesis and production ability of plants (Cho et al., 1994).

Genetic resources used for developing variety include modern varieties, breeding lines, ecotypes, domestic varieties, wild types, and weed types (Boller \& Greene, 2010; Maxted et al., 2008). Among them, modern varieties are very close genetic distance, but have excellent characteristics, and they are widely used as crossing parent. There are several methods of classifying the genetic diversity and relationships of various varieties and genetic resources into clusters by using multivariate analysis (Park et al., 2014), biochemical isozyme (Han et al., 1999), and coefficient of parentage (Zhou et al., 2002; Jong et al., 1999). Multivariate analysis is a method to classify morphological traits objectively and synthetically. Unlike classification by a few traits, several traits are considered simultaneously in selecting various practical uses of breeding as well as evaluation of breeds or genetic resources (Nielsen \& Munck, 2003; Ennis et al., 1982). Studies on classifications of varieties and genetic sources by multivariate analysis has been reported including corn (Park et al., 2014; Choi, 2010), strawberries (Kim et al., 2009), and plum (Choi et al., 2014). Soybean was reported by Lee et al. (1999), Kim et al. (1999), Cho et al. (1994), and Guh et al. (1983), Salami (2013), Malik (2011), and Oliveira et al. (2010). In recent years, methods of using DNA markers have also been used for agricultural researchers (Gosh et al., 2014; Kim et al., 2006). Therefore, this study was conducted to identity the characteristics and variations of leaf-related characters that make up the plant type of soybean varieties developed from 1913 to 2013 in Korea, and to classify these varieties as basic data for soybean breeding programs.

\section{MATERIALS AND METHODS}

A total of 172 varieties of soybean utilized for sauce $\&$ paste (81 varieties), bean sprout (53), cooking with rice (24), vegetable \& early maturing (14) were developed from 1913 to 2013 in Korea (Table 1). On May 28, 2014 , the cultivation of soybean varieties was implemented at the field of Chungbuk National University. The experiment was set up in a randomized complete block design with split-plot design in three independent replications. The fertilization rate was $\mathrm{N}: \mathrm{P}_{2} \mathrm{O}_{5}: \mathrm{K}_{2} \mathrm{O}=3$ : 3: $3.4 \mathrm{~kg} / 10 \mathrm{a}$ and other cultivation management was based from recommendations of Rural Development Administration (RDA).

The leaf length, leaf width, leaf length/width ratio, leaf thickness, leaf area, leaf dry weight, leaf area ratio, petiole length, and petiole weight were investigated during the R6 stage by which the central leaflet of the second leaf from the top of the plant was selected to measure leaf characters. The leaf length, leaf width, leaf length/width ratio, and leaf area were measured using LI-3100, leaf thickness were measured using Digital caliper (CD-15CPX). The leaf dry weight and petiole weight were measured after drying for 48 hours in a dryer at $70^{\circ} \mathrm{C}$. Other investigations were conducted in accordance with the criteria for evaluation of plant genetic resources (Rural Development Administration, 1985) and descriptors for soybean (IBPGR, 1984).

Statistical analyses were performed using SAS System for windows (release 9.2; SAS Institute, Cary, NC, USA). Data were analyzed using PROC GLM (general linear models) procedure and means were separated on the basis of Duncan multiple range test (SAS Institute, 2007). Significances were set at the 5\% level. After performing the Principal Component analysis (PCA), the cluster analysis was performed using the Complete Linkage Cluster method by means of the main component score.

\section{RESULTS AND DISCUSSION}

\section{Variation of leaf-related characters}

The variation of the leaf-related characters of developed varieties is shown in Table 2 and Fig. 1. Based on the result of the 172 varieties, the average leaf length was $13.15 \mathrm{~cm}$ ranging from 6.48 to $17.67 \mathrm{~cm}$. The average leaf width was $7.26 \mathrm{~cm}$ with a range of 2.49 to $12.13 \mathrm{~cm}$. The mean of leaf length/width ratio was 1.89 ranging from 1.16 

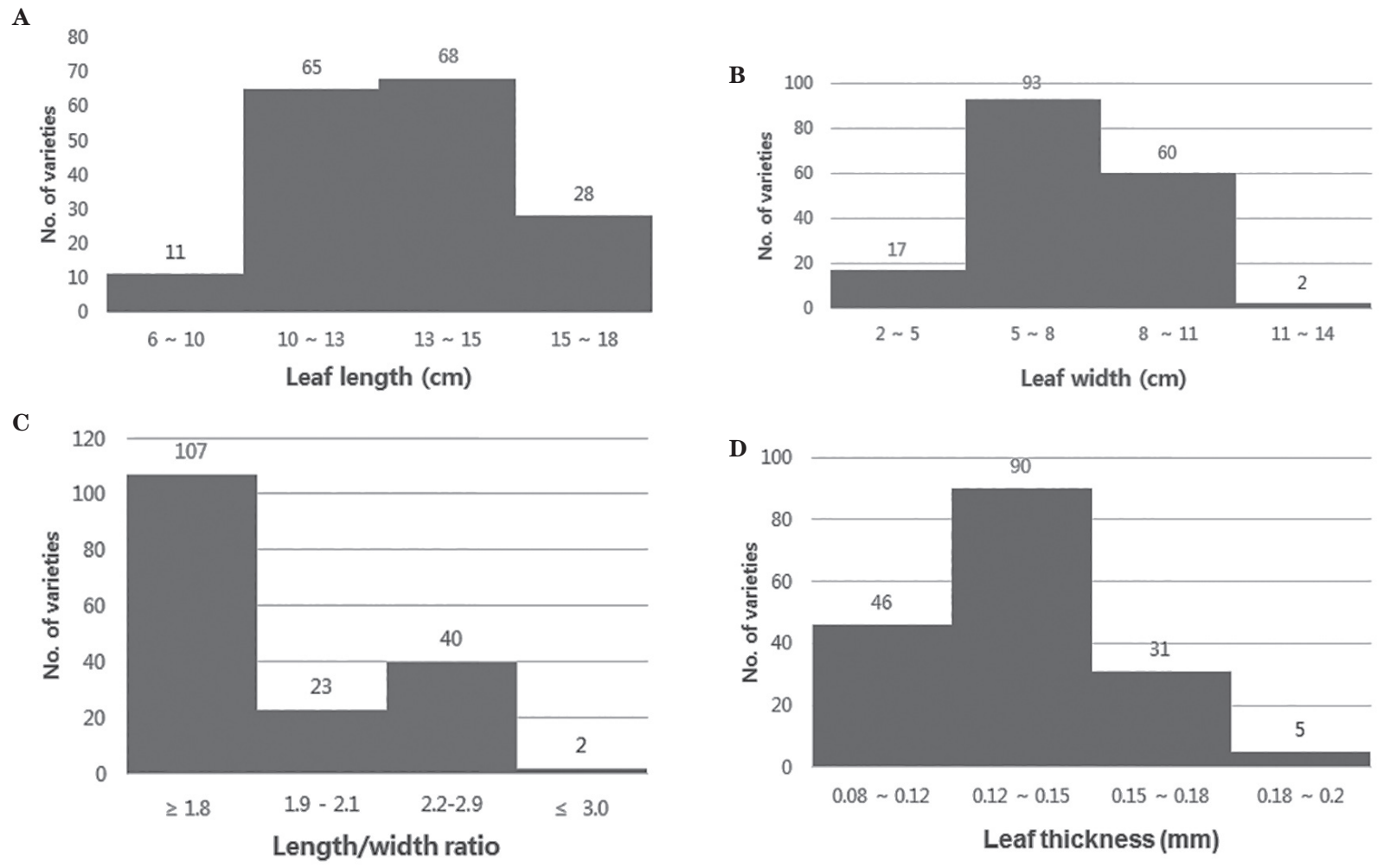

E
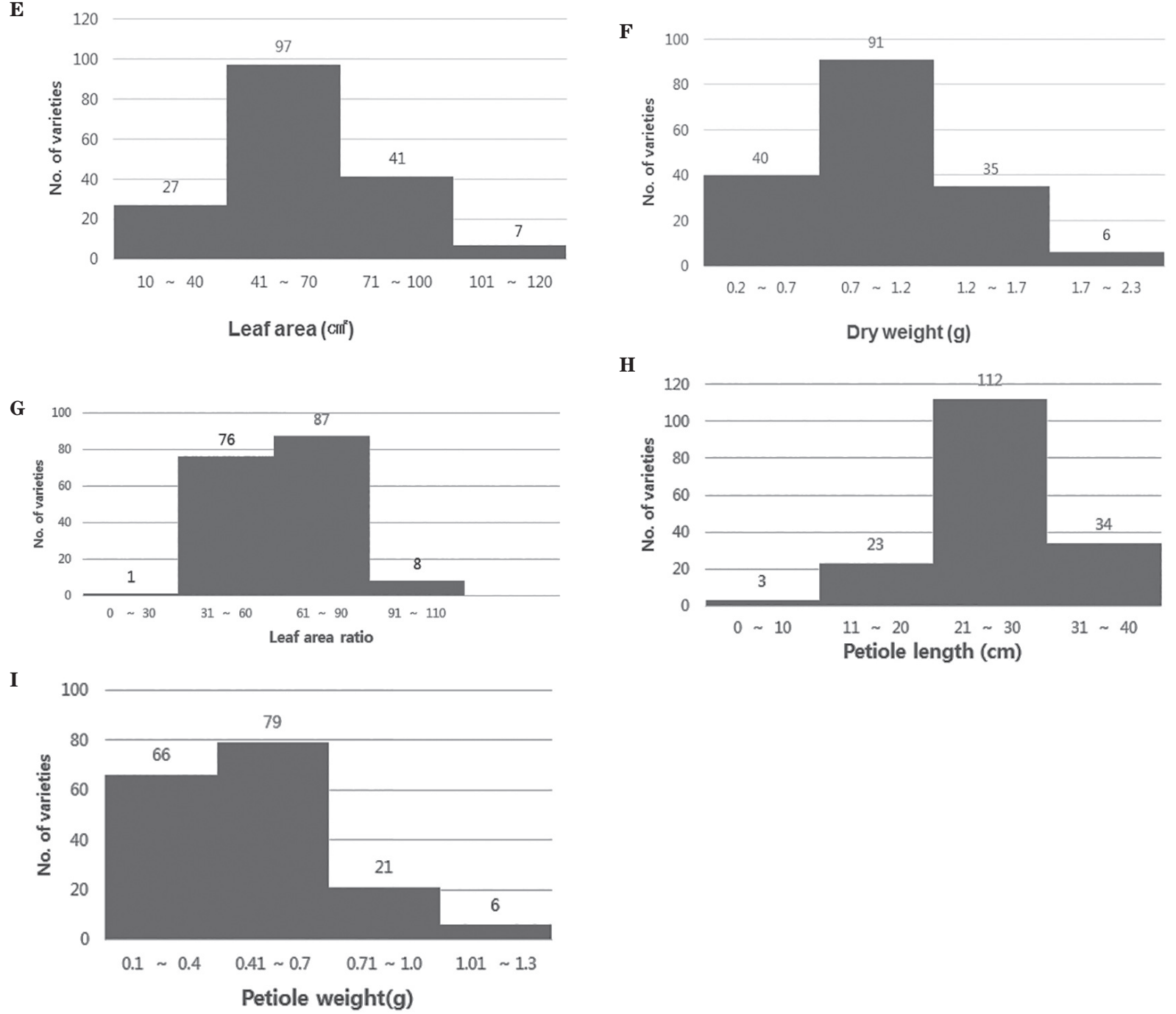

Fig. 1. Frequency distributions of leaf length (A), leaf width (B), length/width ratio (C), leaf thickness (D), leaf area (E), dry weight (F), leaf area ratio (G), petiole length (H) and petiole weight (I) in 172 Korean soybean varieties. 
Table 2. Maximum, minimum, mean and coefficient of variation (CV) of leaf-related characters in 172 Korean soybean varieties

\begin{tabular}{lccccccccc}
\hline \multicolumn{1}{c}{ Statistics } & $\begin{array}{c}\text { Leaf length } \\
(\mathrm{cm})\end{array}$ & $\begin{array}{c}\text { Leaf } \\
\text { width } \\
(\mathrm{cm})\end{array}$ & $\begin{array}{c}\text { Leaf length/ } \\
\text { width ratio }\end{array}$ & $\begin{array}{c}\text { Leaf } \\
\text { thickness } \\
(\mathrm{mm})\end{array}$ & $\begin{array}{c}\text { Leaf area } \\
\left(\mathrm{cm}^{2}\right)\end{array}$ & $\begin{array}{c}\text { Leaf dry } \\
\text { weight } \\
(\mathrm{g})\end{array}$ & $\begin{array}{c}\text { Leaf area } \\
\text { ratio }\end{array}$ & $\begin{array}{c}\text { Petiole } \\
\text { length } \\
(\mathrm{cm})\end{array}$ & $\begin{array}{c}\text { Petiole } \\
\text { weight } \\
(\mathrm{g})\end{array}$ \\
\hline Max. & 17.67 & 12.13 & 3.01 & 0.20 & 108.80 & 101.96 & 2.08 & 38.80 & 1.19 \\
Min. & 6.48 & 2.49 & 1.16 & 0.08 & 10.82 & 6.39 & 0.21 & 6.30 & 0.11 \\
Mean & 13.15 & 7.26 & 1.89 & 0.13 & 59.57 & 63.37 & 0.98 & 25.47 & 0.49 \\
S.D. & 2.01 & 1.71 & 0.45 & 0.02 & 19.45 & 12.90 & 0.36 & 5.58 & 0.23 \\
C.V(\%) & 15.27 & 23.59 & 24.01 & 16.67 & 32.65 & 20.35 & 37.02 & 21.90 & 47.18 \\
\hline
\end{tabular}

Table 3. Varieties with maximum and minimum values of leaf-related characters in 172 Korean soybean varieties

\begin{tabular}{lcccccccccc}
\hline \multicolumn{1}{c}{ Statistics } & $\begin{array}{c}\text { Leaf } \\
\text { length }\end{array}$ & $\begin{array}{c}\text { Leaf } \\
\text { width }\end{array}$ & $\begin{array}{c}\text { Leaf length/ } \\
\text { width ratio }\end{array}$ & $\begin{array}{c}\text { Leaf } \\
\text { thickness }\end{array}$ & $\begin{array}{c}\text { Leaf } \\
\text { area }\end{array}$ & $\begin{array}{c}\text { Leaf dry } \\
\text { weight }\end{array}$ & $\begin{array}{c}\text { Leaf area } \\
\text { ratio }\end{array}$ & $\begin{array}{c}\text { Petiole } \\
\text { length }\end{array}$ & $\begin{array}{c}\text { Petiole } \\
\text { weight }\end{array}$ \\
\hline Max. & $\begin{array}{c}\text { Cheong } \\
\text { yeob1 }\end{array}$ & Saeol & Aga 8 & Tawon & Gipung & Daeyang & Chungbukbaek & Jangsu & Daeyang \\
Min. & Haessal & Gangil & Geomjeongsaeol & Seonam & Haessal & Haessal & Gangil & Gangil & Haessal \\
\hline
\end{tabular}

to 3.01. IBPGR (1984) classified leaflet shape by means of leaf length/width ratio, the range of the leaf length/ width ratio of 1.8 or less was classified as oval leaf type, classified under ovate leaf type has a range of 1.9 to 2.1 while lanceolate leaf type has a range of 2.2 or more. Kim et al. (2008) reported that the leaf length/width ratio, based on IBPGR, was classified as oval with $\mathrm{LSI} \leq 2.0$, ovate with LSI 2.1 3.0 and lanceolate with $3.1 \leq \mathrm{LSI}$. The percentage of oval, ovate and lanceolate leaf types among cultivars were $78.7 \%, 17.0 \%$ and $4.3 \%$, respectively, while wild soybean accessions were 40\%, $15.4 \%$ and $4.4 \%$, respectively (Kim et al., 2008).

The mean value of leaf dry weight was $63.37 \mathrm{~g}$ (a range of 6.39 to $101.96 \mathrm{~g}$ ). The mean of leaf area ratio was 0.98 (a range of 0.21 to 2.08). The average length of petiole length was $25.47 \mathrm{~cm}$ (a range of 6.30 to $38.80 \mathrm{~cm}$ ). The mean value of petiole weight was $0.49 \mathrm{~g}$ (a range of 0.11 to $1.19 \mathrm{~g}$ ) (Table 2). Nakamura et al. (1994) reported that leaf shape of ovate is good for securing leaf area of early growth but it is advantageous for majority due to high growth rate, but it causes over luxuriant growth and light interception defect in the late stage of growth, and Leaf shape of lanceolate is advantageous in light interception of the community and lodging resistance, but it is disadvantageous in securing leaf area at the early stage of growth. The reason for the high yielding ability and lodging resistance of recently developed varieties is that they have the merits of intermediate between ovate and lanceolate.

The coefficient of variation of the leaf characteristics of Korean soybean varieties was $15.27 \%$ in leaf length, $23.59 \%$ in leaf width, $24.01 \%$ in leaf width ratio, $16.67 \%$ in leaf thickness, $32.65 \%$ in leaf area, $20.35 \%$ in leaf dry weight, $37.02 \%$ in leaf area ratio, $21.9 \%$ in petiole length, and $47.18 \%$ in petiole weight (Table 2). Kim et al. (2008) reported that developed soybean varieties from 1913 to 2000 has the largest variation in the leaf-related characters, followed by the large variation of petiole angle and the leaflet length/width ratio.

Among the leaf-related characters of the 172 varieties, "Cheongyeol 1" variety showed the maximum leaf length, while the minimum was "Haessal", the maximum leaf width was "Saeol" and the minimum was "Gangil", the maximum leaf length/width ratio was "Aga 8" and the minimum was "Geomjeongsaeol", the maximum leaf thickness was "Tawon" and the minimum was "Seonam", the maximum leaf area was "Gipung" and the minimum was "Haessal", the maximum leaf dry weight was "Daeyang" and the minimum was "Haessal", the maximum leaf area ratio was "Chungbukbaek" and the minimum was "Gangil", the maximum petiole length was "Sangsu" and the minimum was "Gangil", and lastly, the maximum petiole weight was "Daeyang" and the minimum was "Haessal" (Table 3).

The mean leaf length of 68 soybean varieties ranged from 13 to $15 \mathrm{~cm}$. The shortest length, which ranges from 6 to $10 \mathrm{~cm}$, was observed in 11 varieties. Majority of the varieties (93) exhibited narrow leaf width which measured from 5 to $8 \mathrm{~cm}$, while 11 varieties showed wider leaf which measured from 11 to $14 \mathrm{~cm}$. A total of 89 varieties showed the most common leaf length to width ratio, which was less than 1.8, and the remaining few varieties showed a much higher ratio value at 3.0 or more. The leaf thickness value, which ranges from 0.12 to $0.15 \mathrm{~mm}$ was commonly found in 90 varieties while 0.18 to $0.2 \mathrm{~mm}$ thickness was only observed in 5 varieties. The leaf area ranging from $40 \sim 70 \mathrm{~cm}^{2}$ was observed in 97 varieties, while the remaining 7 varieties displayed a $100 \sim 120 \mathrm{~cm}^{2}$ leaf area. The leaf dry weight varies from 0.7 to $1.2 \mathrm{~g}$ in 91 varieties and 1.7 2.3 g among 6 remaining varieties. The leaf area ratio ranged from 60 to 90 in 87 varieties and 0 to 30 in only one variety. Petiole length ranging from 20 to $30 \mathrm{~cm}$ was observed in 112 varieties, while 0 to $10 \mathrm{~cm}$ long petiole was observed only in 3 varieties. Nakaseko (1988) reported that short petiole length of the plant type improved light penetration in the community. The range of petiole weight was 1.0 to $1.3 \mathrm{~g}$ in 6 varieties and 0.4 0.7 g was mostly observed in 79 varieties (Fig. 1).

The leaf length and leaf width as well as petiole weight and leaf dry weight had positive correlation, while leaf width and leaf length/width ratio were negatively correlated $(\mathrm{r}=-0.7563)$ (Fig 2$)$. 
A

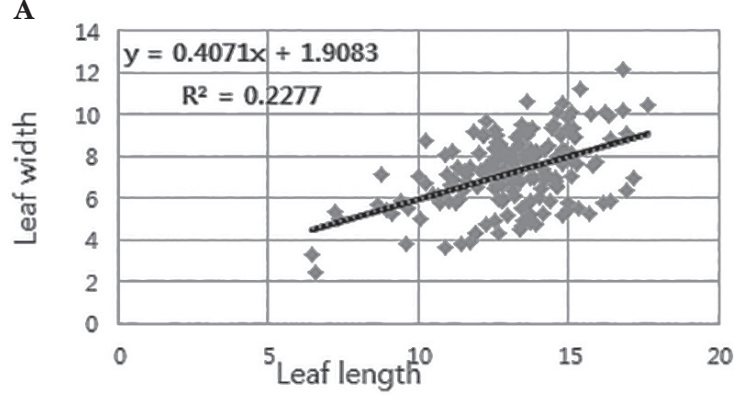

C

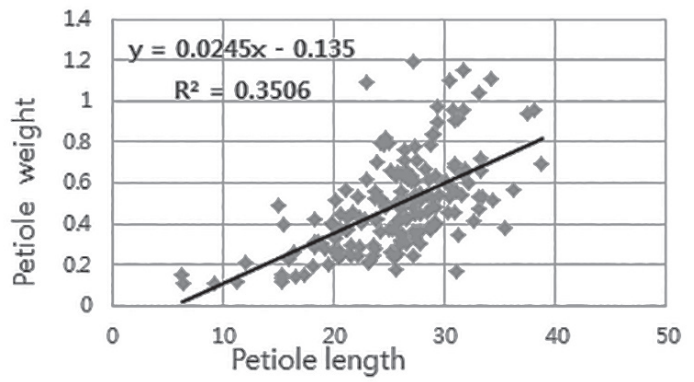

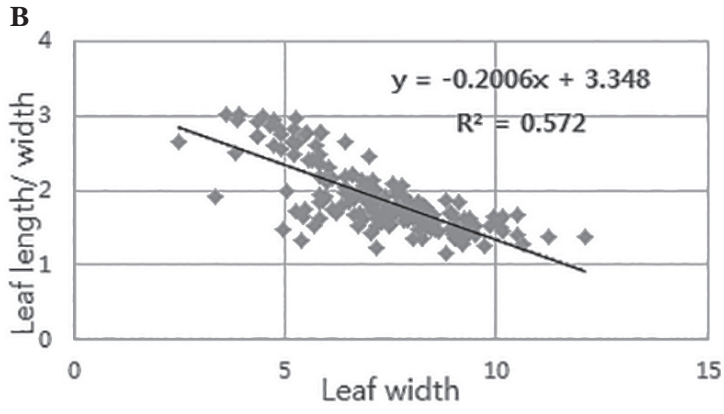

D

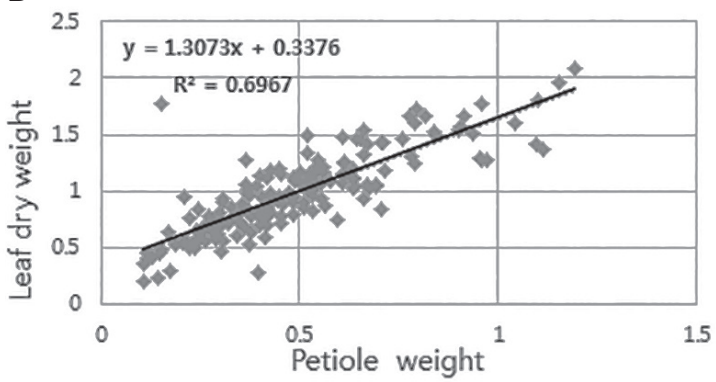

Fig. 2. Relationship between leaf-related (leaf width and leaf length; A, Leaf length/width and leaf width; B, petiole weight and petiole length; C, leaf dry weight and petiole weight; D) characters in 172 Korean soybean varieties.

\section{Principal component analysis}

As a result of the analysis of the principal components using the nine leaf-related characters, the obtained eigenvalue and the contribution of each principal component are shown in Table 4. The contribution of the main component to the total was $50.2 \%$ for the first main component, $20.5 \%$ for the second main component, $14.2 \%$ for the third main component. The cluster classification is performed by selecting only the principal components that explain the variation of the data among the nine principal components, and generally determines the number of principal components with an eigenvalue of 1 or more (Janmohammadi et al., 2014). Therefore, principal component analysis of nine leaf characters revealed that the cumulative contribution from the first to the third main component was $84.9 \%$, and it was possible to classify Korean soybean varieties only with the three main components. The first main component showed a high positive correlation with all components except for leaf length/width ratio and leaf area. The second main component showed negative correlation with leaf length/width ratio, leaf thickness and leaf dry weight, and positive correlation with leaf width, leaf area, leaf area ratio and petiole length. The third main component showed negative correlation with leaf width, and positive correlation with leaf length and leaf length/width ratio (Table 5).

\section{Clustering of 172 soybean varieties}

As a result of cluster analysis using the first to third main components, 172 Korean soybean varieties were divided into 6 clusters based on average distance 1.5 (Fig. 3). The total number of varieties is classified as 66
Table 4. Eigenvalues and contribution obtained from principal component analysis in 172 Korean soybean varieties

\begin{tabular}{cccc}
\hline \multicolumn{4}{c}{ Eigenvalues of the Correlation Matrix } \\
\hline $\begin{array}{c}\text { Principal } \\
\text { component }\end{array}$ & Eigenvalue & Proportion (\%) & Cumulative (\%) \\
\hline Prin 1 & 4.519 & 50.2 & 50.2 \\
Prin 2 & 1.849 & 20.5 & 70.7 \\
Prin 3 & 1.280 & 14.2 & 84.9 \\
Prin 4 & 0.605 & 6.7 & 91.7 \\
Prin 5 & 0.427 & 4.7 & 96.4 \\
Prin 6 & 0.187 & 2.0 & 98.5 \\
Prin 7 & 0.089 & 1.0 & 99.5 \\
Prin 8 & 0.021 & 0.2 & 99.7 \\
Prin 9 & 0.019 & 0.2 & 100 \\
\hline
\end{tabular}

Table 5. Correlation coefficients between leaf-related characters and principal components in 172 Korean soybean varieties

\begin{tabular}{lcll}
\hline \multirow{2}{*}{\multicolumn{1}{c}{ Characters }} & \multicolumn{2}{c}{ Principal component } & \\
\cline { 2 - 4 } & Prin 1 & Prin 2 & Prin 3 \\
\hline Leaf length (cm) & $0.643^{* *}$ & 0.148 & $0.675^{* *}$ \\
Leaf width (cm) & $0.903^{* *}$ & $0.205^{* *}$ & $-0.291^{* *}$ \\
Leaf length/ width ratio & $-0.535^{* *}$ & $-0.151^{*}$ & $0.819^{* *}$ \\
Leaf thickness (mm) & $0.247^{* *}$ & $-0.817^{* *}$ & -0.081 \\
Leaf area (cm $\left.{ }^{2}\right)$ & $0.946^{* *}$ & $0.162^{*}$ & 0.048 \\
Leaf dry weight (g) & $0.886^{* *}$ & $-0.354^{* *}$ & 0.04 \\
leaf area ratio & $-0.188^{*}$ & $0.896^{* *}$ & -0.06 \\
Petiole length (cm) & $0.619^{* *}$ & $0.368^{* *}$ & $0.223^{* *}$ \\
Petiole weight $(\mathrm{g})$ & $0.916^{* *}$ & -0.06 & 0.06 \\
\hline
\end{tabular}

*** Significant at the level of 0.05 and 0.01 probability, respectively. 


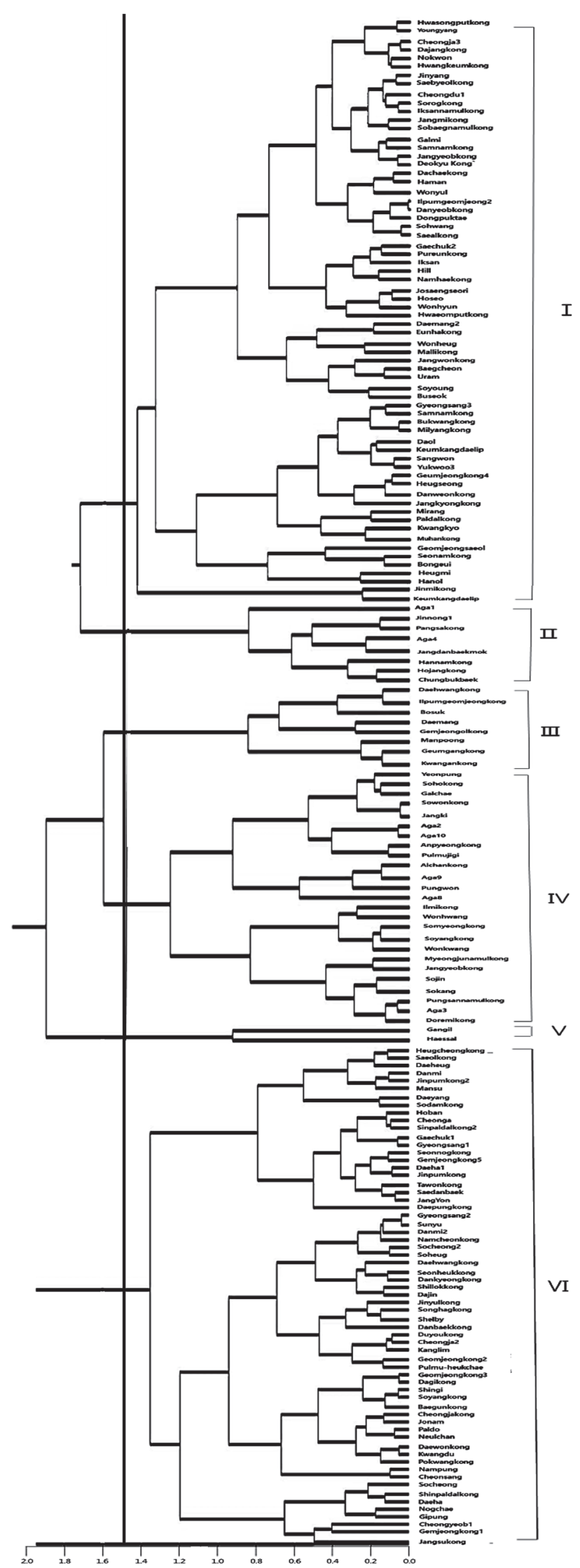

Fig. 3. Dendrogram classified by complete linkage cluster based on principal component scores in 172 Korean soybean varieties.
(38.4\%) in cluster I, 8 (4.7\%) in cluster II, 8 (4.7\%) in cluster III, 25 (14.53\%) in cluster IV, 2 (1.2\%) in cluster $\mathrm{V}$, and $63(36.62 \%)$ in cluster VI. About $75.1 \%$ of the total number of varieties belong to cluster I and VI. The cluster I had above-average values for all of the leafrelated characters, meanwhile cluster II had the smallest leaf thickness of $0.11 \mathrm{~mm}$, with the highest leaf area ratio of 80.36. The cluster III had the smallest leaf width of 1.5 , and the leaf thickness was the largest at $0.17 \mathrm{~mm}$. The cluster IV had the largest leaf width ratio of 2.7 , and the other leaf-related characters were less than average. The cluster $\mathrm{V}$ had the lowest value among the clusters except for the leaf length/width ratio, leaf thickness and leaf dry weight. The cluster VI had the highest value in all of the traits except leaf length/width ratio, leaf thickness, and leaf area ratio (Table 6 ).

There were 12 (7.0\%) varieties developed before the $1980 \mathrm{~s}$ in the cluster I, 2 (1.2\%) varieties in the cluster II, and non to the cluster III and V, $3(1.7 \%)$ varieties in the cluster VI. In the $1980 \mathrm{~s}, 11$ (6.3\%) varieties were found in the cluster I, $1(0.6 \%)$ variety was included in the cluster II, and 5 (2.9\%) varieties were included in the cluster VI. In the 1990s, there were 12 (6.9\%) varieties in the cluster I, $1(0.6 \%)$ variety in the cluster II, 7 (4.0\%) varieties in the cluster $\mathrm{IV}$ and 19 (11.0\%) varieties in the cluster VI. Since 2000, there were 31 (18.0\%) varieties in the cluster I, 4 (2.3\%) varieties in the cluster II, 17 (9.9\%) varieties in the cluster $\mathrm{IV}, 2$ (1.2\%) varieties belonged to the cluster V 36 (20.9\%) varieties belonged to the cluster VI, comprising about $54.7 \%$ of the total varieties developed since 2000 (Table 7).

No cultivars were found in III and V clusters that produced before 1980, and no cultivars in 1980s were included in III, IV and V, and none of the cultivars of 1990 belong to cluster V. Varieties that are released after the 2000s were included in each cluster. Comparison of leaf characters contents based on utilization types showed that sauce \& paste belong both in clusters I and VI, bean sprout in I and VI, cooking with rice in I, and vegetable \& early maturing in VI. Growth and leaf-related characteristics or traits are poor in cluster $\mathrm{V}$ and is good in cluster VI. The soybean varieties of Korea were distributed in clusters I, II, IV, and VI before 1980, but they were widely distributed in whole clusters since the 1990s. This is because various varieties were developed after the mid1990 s, with the aim of breeding diversification and quality upgrading in response to the international opening (Kim et al. 2006).

The cluster is classified by utilization type as shown in Table 8. In the cluster I, 36 (20.9\%) varieties were for sauce \& paste, while 17 (9.9\%) varieties for bean sprout, $9(5.3 \%)$ varieties for cooking with rice, and 4 (2.3\%) varieties for vegetable \& early maturing were included. The cluster II and III did not include any kind of vegetable \& early maturing, while cluster IV contained 4 (2.3\%) varieties of sauce \& paste and 21 (12.2\%) varieties included for bean sprout, and for cooking with rice and vegetable \& early maturing variety did not include any cluster. In the $\mathrm{V}$ group, $2(1.2 \%)$ varieties were for sauce \& paste, while 32 (18.6\%) varieties for sauce \& 
Table 6. Mean values of leaf-related characters of each cluster classified in 172 Korean soybean varieties

\begin{tabular}{|c|c|c|c|c|c|c|c|}
\hline \multirow[b]{2}{*}{ Characters } & \multicolumn{6}{|l|}{ Cluster } & \multirow[b]{2}{*}{ Mean } \\
\hline & $\begin{array}{c}\mathrm{I} \\
(\mathrm{n}=66)\end{array}$ & $\begin{array}{c}\text { II } \\
(n=8)\end{array}$ & $\begin{array}{c}\text { III } \\
(n=8)\end{array}$ & $\begin{array}{c}\mathrm{IV} \\
(\mathrm{n}=25)\end{array}$ & $\begin{array}{c}V \\
(n=2)\end{array}$ & $\begin{array}{c}\text { VI } \\
(n=63)\end{array}$ & \\
\hline Leaf length $(\mathrm{cm})$ & 12.75 & 9.15 & 10.61 & 13.42 & 6.53 & 14.48 & 11.15 \\
\hline Leaf width $(\mathrm{cm})$ & 7.21 & 5.16 & 7.15 & 4.95 & 2.93 & 8.63 & 6.05 \\
\hline Leaf length/width ratio & 1.80 & 0.18 & 1.5 & 2.73 & 2.29 & 1.71 & 1.7 \\
\hline Leaf thickness (mm) & 0.12 & 0.11 & 0.17 & 0.14 & 0.17 & 0.14 & 0.14 \\
\hline Leaf area $\left(\mathrm{cm}^{2}\right)$ & 56.06 & 30.30 & 45.81 & 41.52 & 11.07 & 77.11 & 43.64 \\
\hline Leaf dry weight (g) & 0.83 & 0.39 & 0.96 & 0.7 & 0.99 & 1.32 & 0.85 \\
\hline leaf area ratio & 69.03 & 80.13 & 47.35 & 61.18 & 29.33 & 59.21 & 57.70 \\
\hline Petiole length $(\mathrm{cm})$ & 26.15 & 18.48 & 20.22 & 22.55 & 6.4 & 28.13 & 20.33 \\
\hline Petiole weight (g) & 0.42 & 0.21 & 0.32 & 0.31 & 0.13 & 0.71 & 0.26 \\
\hline
\end{tabular}

Table 7. Number of varieties of each cluster classified by released years in 172 Korean soybean varieties

\begin{tabular}{|c|c|c|c|c|c|c|c|}
\hline \multirow[b]{2}{*}{$\begin{array}{l}\text { Released } \\
\text { year }\end{array}$} & \multicolumn{6}{|l|}{ Cluster } & \multirow[b]{2}{*}{ Total } \\
\hline & $\begin{array}{c}I \\
(n=66)\end{array}$ & $\begin{array}{c}\mathrm{I} \\
(\mathrm{n}=8)\end{array}$ & $\begin{array}{c}\text { III } \\
(n=8)\end{array}$ & $\begin{array}{c}\mathrm{IV} \\
(\mathrm{n}=25)\end{array}$ & $\begin{array}{c}\mathrm{V} \\
(\mathrm{n}=2)\end{array}$ & $\begin{array}{c}\text { VI } \\
(n=63)\end{array}$ & \\
\hline Before 1980 & $12(7.0)$ & $2(1.2)$ & - & $1(0.6)$ & - & $3(1.7)$ & $18(10.4)$ \\
\hline $1980 \mathrm{~s}$ & $11(6.3)$ & $1(0.6)$ & - & - & - & $5(2.9)$ & $17(9.9)$ \\
\hline $1990 \mathrm{~s}$ & $12(6.9)$ & $1(0.6)$ & $4(2.3)$ & $7(4)$ & - & $19(11)$ & $43(25)$ \\
\hline Form 2000 to 2013 & $31(18)$ & $4(2.3)$ & $4(2.3)$ & $17(9.9)$ & $2(1.2)$ & $36(21)$ & $94(54.7)$ \\
\hline Total & $66(38.4)$ & $8(4.6)$ & $8(4.6)$ & $25(14.5)$ & $2(1.2)$ & $63(36.7)$ & $172(100)$ \\
\hline
\end{tabular}

( ): Percentage of varieties belongs to each cluster to a total of varieties.

Table 8. Number of varieties of each cluster classified by utilization types in 172 Korean soybean varieties

\begin{tabular}{|c|c|c|c|c|c|c|c|}
\hline \multirow{2}{*}{$\begin{array}{c}\text { Utilization } \\
\text { Type }\end{array}$} & \multicolumn{6}{|l|}{ Cluster } & \multirow[b]{2}{*}{ Total } \\
\hline & $\begin{array}{c}I \\
(n=66)\end{array}$ & $\begin{array}{c}\text { II } \\
(n=8)\end{array}$ & $\begin{array}{c}\text { III } \\
(n=8)\end{array}$ & $\begin{array}{c}\text { IV } \\
(n=25)\end{array}$ & $\begin{array}{c}\mathrm{V} \\
(\mathrm{n}=2)\end{array}$ & $\begin{array}{c}\text { VI } \\
(n=63)\end{array}$ & \\
\hline Sauce \& paste & $36(21)$ & $3(1.7)$ & $4(2.3)$ & $4(2.3)$ & $2(1.2)$ & $32(18.7)$ & $81(47)$ \\
\hline Bean sprout & $17(9.9)$ & $4(2.3)$ & $3(1.7)$ & $21(12.2)$ & - & $8(4.6)$ & $53(31)$ \\
\hline Cooking with rice & $9(5.2)$ & $1(0.6)$ & $1(0.6)$ & - & - & $13(7.6)$ & $24(14)$ \\
\hline $\begin{array}{l}\text { Vegetable \& } \\
\text { early maturing }\end{array}$ & $4(2.3)$ & - & - & - & - & $10(6)$ & $14(8)$ \\
\hline Total & $66(38.4)$ & $8(4.7)$ & $8(4.7)$ & $25(14.5)$ & $2(1.2)$ & $63(36.7)$ & $172(100)$ \\
\hline
\end{tabular}

( ): Percentage of varieties belongs to each cluster to a total of varieties.

paste, 8 (4.5\%) varieties for bean sprout, 13 (7.6\%) varieties for cooking with rice, and 10 (5.8\%) varieties for vegetable \& early maturing were included in the cluster VI. By the utilization type, the varieties for sauce \& paste were distributed in cluster I, the varieties for bean sprout were distributed in clusters I and VI, the varieties for cooking with rice were distributed in cluster VI, and the varieties for vegetable \& early maturing were distributed in cluster VI, respectively.

Based on the coefficient of parentage, soybean varieties in the United States and Canada were low in genetic diversity (Gizlice et al., 1993), (China (Cui et al., 2000) from and Japan (Zhou et al., 2002)) and soybean varieties were high in genetic diversity. Li \& Nelson (2001) reported that the genetic diversity of Chinese soybean varieties was higher than Korea and Japan soybean varieties. Chinese soybean varieties are genetically distinct from Korean and Japanese soybean varieties, and soybean varieties between Korean and Japanese were closely genetically related. Jong et al. (1999) analyzed 75 varieties of soybeans developed in Korea until 1998 on the basis of coefficient of parentage, and found that genetic diversity was high. Kim et al. (2006) classified 99 varieties of Korean soybeans developed until 2002 into seven groups by SSR markers, and reported that Korean soybean varieties had relatively high genetic diversity. These results are related to the genetic diversity of soybean varieties. In this study, we explored the variation of leaf-related characteristics of 172 soybean varieties in Korea from 1913 to 2013 and classified them into varieties by multivariate analysis to schematize the flexible relationship. This study will be useful for information on the genetic diversity and flexible relationship of Korean soybean varieties. 


\section{AUTHOR CONTRIBUTIONS}

T. Y. HWANG, and S. C. GWAK designed the experiment. J. SUNG and J. W. CHUNG analyzed the data. Y. SHINOGI commented on the manuscript. T. K. OH and H. S. KIM supervised the work. All authors assisted in editing the manuscript and approved the final version. The authors declare that the research was conducted in the absence of any commercial or financial relationships that could be construed as a potential conflict of interest.

\section{ACKNOWLEDGEMENTS}

This work was conducted during the research year of Chungbuk National University in 2018.

\section{REFERENCES}

Ariga, T. 1943 Classification of soybean varieties according to plant type. Agri. and Hort. 18: 69-670

Boller, B. and S. L. Greene 2010 Genetic resources. In: B. Boller, UK. Posselt, F. Veronesi (eds). Fodder crops and amenity grasses, Handbook of Plant Breeding, 5. Springer Science+Business Media, New York, pp.13-38

Cho, C. H., Y. G. Seong and S. M. Kim 1994 Classification of soybean genotypes based on seasonal response of flowering, and maturity by principal component analysis. Korean J. Breed. 26(4): 405-413

Choi, H. G. 2010 Assessment of major physicochemical components on waxy corn hybrids (Zea mays L.). PhD thesis. pp. 123. Department of Agronomy, Graduate School, Chungnam National University

Choi, G. B., K. H. Hyun and D. Y. Shin 2014 Multivariate analysis on quantitative characteristics of Prunus mume. Korean J. Plant Res. 27(1): 089-094

Cui, Z., T. E. Carter and J. W. Burton 2000 Genetic diversity pattems in Chinese soybean cultivars based on coefficient of parentage. Crop Sci. 40: 1780-1793

Dornoff, D. C. and R. M. Shibles 1970 Varietal differences in net photosynthesis of soybean leaves. Crop Sci. 10: 42-45

Ennis, D. M., H. Boelens, H. Haring and P. Bowman 1982 Multivariate analysis in sensory evaluation. Food Technol. pp. 83-90

Gizlice, Z., T. E. Carter and J. W. Burton 1993 Genetic diversity in North American soybean 1. multivariate analysis of founding stock and relation to coefficient of parentage. Crop Sci. 33 614-620

Ghosh, J. P., D. Ghosh and P. R. Choudhury 2014 An assessment of genetic relatedness between soybeans [Glycine max (L.) Merrill] cultivars using SSR markers. American J. Plant Sci. 5(20): 3089-3096

Guh, J. O., Y. M. Lee and D. Y. Shin 1983 Basic studies on the native colored-soybean cultivars II. Classification of collected soybean varieties by the multivariate analysis. Korean J. Crop Sci. 28(3): 340-344

Haile, F. J., L. G. Higley, J. E. Specht and S. M. Spomer 1998 Soybean leaf morphology and defoliation tolerance. Agron.J. 90: 353-362

Han, O, J. and Y. Shimamoto 1999 Genetic diversity of soybean landraces in Korea. Korean J. Crop Sci. 44(3): 256-262.

IBPGR. 1984. Descriptors for soybean. IBPGR Secretariat, Rome Italy. pp. 38

Jeong, N., S. J. Suh, M. H. Kim, S. Lee, J. K. Moon, H. S. Kim and S. C. Jeong 2012 LN is a key regulator of leaflet shape and number of seeds per pod in soybean. The plant cell 24(12): 4807-4818

Janmohammadi, M., N. Sabaghnia. and M. Nouraein 2014 Path Analysis of Grain Yield and Yield Components and Some
Agronomic Traits in Bread Wheat. Acta Univ. Agric. Silvic Mendelianae Brun. 62(5): 945-952

Jong, S. K., H. S. Kim and S. Y. Son 1999 Genetic diversity using pedigree analysis in Korean soybean varieties. Korean J. Breed. 31(4): 313-322

Kim, D. Y., M. K. Yoon, J. H. Kwak, T. I. Kim and J. H. Kim 2009 Classification of strawberry germplasms based on horticultural traits and principal component analysis. Korean J. Hort Sci. Technol. 27(4): 636-643

Kim, H. S., K. H. Lee, H. L. Song, G. H. Kim, S. H. Woo and S. G. Jeong 2008 Canopy-related characteristics of Korean soybean cultivars. Korean J. Breed. Sci. 40(2): 143-152

Kim, S. H., J. W. Jung, J. K. Moon, S. H. Woo, Y. G. Cho, S. K. Jong and H. S. Kim 2006 Genetic diversity and relationship by SSR markers of Korean soybean cultivars. Korean J. Crop Sci. 51(3): 248-258

Kim, Y. J., S. K. Suh, H. S. Kim, H. K. Park and M. S. Park 1999 Classification of soybean accessions by morphological characteristics. Korean J. Breed Sci. 31: 132-137

Lee, G. Y., Y. S. So, H. S. Kim, J. H. Hong, E. K. Jang, K. H. Lee, G. S. Yun and S. G. Hwang 2015 Variation of Growth and Yield Component Characters and Varietal Classification by Multivariate Analysis in Korean Soybean Varieties. Korean J. Int. Agric. 27(3): 348-357

Li, Z. and R. L. Nelson 2001 Genetic diversity among soybean accessions from three countries measured by RAPDs. Crop Sci. 41: $1337-1347$

Lugg, D. G. and T. R. Sinclair 1981 Seasonal changes in photosynthesis of field-grown soybean leaflets. I. Relation to leaflet dimensions. Photosynthetica 15: 129-137

Malik, M. F. A. 2011 Evaluation of genetic diversity in bean (Glycinemax (L.) genotypes based on agronomic and biochemical traits. PhD thesis. pp. 170. Quaid-i-Azam University

Maxted, N., J. Iriondo, E. Dulloo and A. Lane 2008 Introduction: The integration of PGR conservation with protected area management. In: Iriondo, J.M., Maxted, N. and Dulloo, E.(Eds.), Plant Genetic Population Management. pp. 1-22. CAB International, Wallingford

Nagata, T. 1950 Studies on characteristics of soybean varieties. Society of Japan soybean. Tokyo. pp 115

Nakamura, S., I. Basa and K. Takahashi 1994 Characteristics of leaflets of soybean cultivar. Tohoku J. crop Science. 37: 69-70

Nakamura, S., T. Koyama, I. Watanabe and K. Sasaki 1981 Varietal grouping of soybeans according to the branching direction and its response to planting pattern. Bull. Tohoku Natl. Agric. Exp. Stn. 65: $59-71$

Nakaseko, K. 1988 Productivity of a dwarf type soybean induced by mechanical stimulation applied during vegetative stage. Jpn. J. Crop Sci. 57: 782-789

Nielsen, J. P. and L. Munck 2003 Evaluation of malting barley quality using exploratory data analysis. I. Extraction of information from micro malting data of spring and winter barley. J. Cereal Sci. 38: $173-180$

Oliveira, M. F., R. L. Nelson, I. O. Geraldic, C. D. Cruz and J. F. de. Toledoa 2010 Establishing a soybean germplasm core collection. Field Crops Res. 119: 277-289

Park, J. Y., K. J. Sa, K. J. Park and J. K. Lee 2014 Analysis of morphological characteristics for normal maize inbred lines. Korean J. Crop Sci. 59(3): 312-318

Salimi S. 2013 Relationship of some soybean genotypes based on morphological characters and biochemical marker. International J. Agronomy and Plant production. 4(9): 22372243

Sawada, S. 1988. Inheritance of leaflet shape in soybean. Soybean Genet. News. 15: 61-65

Sawada, S. 1992 Time to determination and variations within and between plants in leaf shape of soybean. Jpn J. Crop Sci. 61: 96-100

Watanabe, I., S. Konno and K. Tabuchi 1975 Revised standard of examination for plant type of soybean. Proc. Crop Sci Japan. 44(4): 479-480

Wells, R., L. L. Schulze, D. A. Ashley, H. R. Boerma and R. H. Brown 
1982 Cultivar difference in canopy apparent photosynthesis and their relationship to seed yield in soybeans. Crop Sci. 22: 886890

Zheng, H. Y. and H. D. Chen 1980 A preliminary study on the resources of wild soybean in Jilin province. Sci. Agric. Sinica.
13: $26-32$

Zhou, X., E. Thomson, Jr. Carter, Z. Cui, S. Miyazaki and J. W. Burton 2002 Genetic diversity patterns in Japanese soybean cultivars based on coefficient of parentage. Crop Sci. 42: 1331-1342 
